\title{
Benefaction of Saline Water Irrigation in Desert Soils "Scope of Salinity Problems and New Means of Control"
}

\author{
M.H. Hilal
}

Soils and Water Use Department, NRC, Giza, Egypt.

XXESSIVE salt concentration in soils and in underground water
has been considered a serious problem in arid and semi-arid
regions for centuries. Removal of excess salts or decreasing their
activity is necessary for optimum crop production and for soil
conservation.

Decreasing the activity of soluble salts in irrigation water proved to correct excessive water salinity. Besides, the realization of proper ionic and nutrients balance in soil solution lead to more successful utilization of saline water irrigation.

Surface soil management, induced soil stratification, proper drying cycle and application of Nile Fertile (a natural sulfur fertilizer mixture) have been suggested as efficient means for promoting saline water irrigation.

Changes in salts and moisture distribution during a drying cycle of stratified soil columns, i.e., $15 \mathrm{~cm}$ sand over $15 \mathrm{~cm}$ sandy loam (S/SL) and the opposite stratification (SL/S), were evaluated. Results revealed that S/SL system has decreased capillary rise and evaporation loss and consequently limited the upward movement of salts. On the other hand, the system SL/S greatly increased evaporation but slightly increased the upward movement of salts. However, such movement in homogenous S or SL soils was much greater than that of stratified systems. Besides, longer drying cycle decreased salt accumulation in root zone and activated upward and downward salt movement, under all conditions of study.

Recently, magnetizing saline irrigation water through a proper magnetic field has been introduced as an effective mean for soil desalination. Magnetic field causes the hydration of salt ions and colloids to slide down, leading to better salt solubility and accelerated coagulation and salt crystallization. The mode of magnetic treatment implies certain influence on the structure of water and soil solution. Besides, the required magnetic field strength depends on salt type and concentration .

In this work the effectiveness of magnetizing water of different salinity, on soil salinity and alkalinity, on ionic balance and ion uptake by plant, was evaluated in a series of pot and field experiments . 
In an olive farm irrigated with moderately saline magnetized water was shown to have 3 main effects: (1) Lowering soil alkalinity, (2) Increasing the leaching of excess soluble salts and (3) Dissolving slightly soluble salts such as phosphates and sulfates .

Such effects were also demonstrated in a citrus orchard where the solubility and uptake of $\mathrm{Ca}, \mathrm{Mg}$ and $\mathrm{SO}_{4}$ were accelerated while $\mathrm{Na}+$ uptake was reduced to one half, by magnetized water.

Keywords: Magnetized water, Salt diffusion, Soil stratification, Drying cycle, Capillary rise, Evaporation, Nile Fertile, Salt tolerant plants.

Saline water irrigation is well known to cause variable hazards to plants; even to the relatively salt tolerant plants which can be seriously affected at excessive salt levels. However, the degree of crop damage is, more or less, related to salt accumulation and distribution around root zone, rather than to salinity level of irrigation water. The instability of desert agro-system is mainly related to salt accumulation in root zone.

Excessive accumulation of salts and underground water has plagued the irrigated arid and semi arid regions of the world for centuries, more over, the wide spread use of saline under ground water will promote the formation of salt affected soils. Removal of excess salts or decreasing their activity is therefore necessary for attaining optimum crop production and preventing the formation of salt affected soil.

Even mangrove, the highly salt tolerant plant was reported to require fresh water to improve its growth.

The selection of salt tolerant plants has been of concern for several years. However, other important salinity control majors such as surface soil management, irrigation scheduling and application of sulfur fertilizer, Corrective techniques to maintain better salinity conditions for plant growth, cultivation and afforestation were suggested by Hilal et al. (1997).

Korkor and Hilal (1976) stated that Wheat crop have been shown to tolerate a level of salts as high as $6000 \mathrm{ppm}$. without significant drop in yield. However, at the germination stage the crop seemed to be more sensitive to salts 
compared with other stages, in this case, significant depression in yield occurred at salt level of $1500 \mathrm{ppm}$.

Applying the S- fertilizer- mixtures, Nile Fertile (NF), can keep salinity under control by inducing $\mathrm{Cl}^{-} / \mathrm{SO}_{4}^{-2}$ balance. $\mathrm{NF}$ also reduces soil $\mathrm{pH}$ and provides better oxidation/reduction conditions for the benefit of plant roots.

Likewise, applying $\mathrm{MgSO}_{4}$ to high concentrations of $\mathrm{NaCl}$ in solution is also capable of causing significant (EC) reduction. Moreover, Ibrahim (1999) has reported that NF-treated field plots were able to drive the highest values of $\mathrm{P}, \mathrm{Fe}$ and $\mathrm{Zn}$ towards the root zones.

The possibility of using magnetized water to desalinate the soil has been stated by Takashincko (1997) to be a very effective means for salinity control. He added that magnetic treated water (MTW) was capable to remove 50 to $80 \%$ of soil $\mathrm{Cl}^{-}$, compared to a removal of only $30 \%$ by normal water. MTW has also doubled the leaching of sulfates and increased $\mathrm{O}_{2}$ content by $10 \%$. red to untreated water.

He has introduced a set of dipole magnetic units for magnetizing irrigation water. The efficiency of using such units for the magnetic treatment of water depends greatly upon water chemical composition and magnetic field strength; the strength required for magnetizing water increases by increasing total salinity.

The mode of magnetic treatment implies a certain influence of magnetic field on the structure of water and aqueous solutions alike. A better salt solubility arises along with kinetic changes in salt crystallization and acceleration of coagulation.

Zhu et al. (1986) has also reported that laboratory tests have showed that desalination of a saline soil was $29 \%$ greater in the first leaching and $33 \%$ greater in the second leaching with magnetized water.

Benefaction of saline water irrigation in desert soils was the main goal of this program. Set of corrective techniques such as magnetic treatment of irrigation water, application of NF (as a soil amendment) and the choice of proper fertilization program were evaluated on different field scales.

In this work, magnetic treatment of Saline water (ranging in salinity between 6 to $11 \mathrm{mS} . \mathrm{cm}^{-1}$ ), fertilization program, farm management and application of Nile-Fertile $^{\circledR}$ (NF) were evaluated, as effective means for improving slat affected regions. Salt, moisture and nutrients distribution in root zone, being the key for good plant performance, were monitored.

A series of field experiments were carried out to evaluate the following : 
1. The effect of salt type and salt activity, in irrigation water, on soil salinity and plant growth.

2. The Corrective techniques: Ionic balance $\left(\mathrm{Cl} / \mathrm{SO}_{4}\right.$ ratio); induced soil stratification; furrow and strip system of cultivation.

3. Optomizing roll of the sulfur fertelizere mixtur (Nile Fertile) and magnetic treated irrigation water.

4. The interaction effects of applied fertilizers and saline water on soil salinity and plant growth.

Salt, moisture and nutrients distribution in root zone, being the key for good plant performance, were monitored. Response of salt tolerant plants, i.e., Olives, Barley, Wheat, Beets and Onion, to such set of corrective techniques, were studied.

\section{Results and Discussion}

Within a complete program for the beneficiation of saline water irrigation and the amendment of salt affected soils. Laboratory tests were conducted to study several salinity aspects of soil water systems. Salt activities, Salt diffusivity, Salt accumulation and distribution in fields and forms of applied fertilizers and their role in soil salinization were investigated.

\section{Salt activity}

Irrigation solutions, containing $10 \mathrm{~g} / \mathrm{L}$ of $\mathrm{Cl}^{-}$salts of $\mathrm{Na}^{+}, \mathrm{Mg}^{+2}$ or $\mathrm{Ca}^{+2}$, differed greatly in their $\mathrm{EC}$ values, $\mathrm{NaCl}$ solution gave an $\mathrm{EC}$ value above $14 \mathrm{mS} . \mathrm{cm}^{-1}$ while $\mathrm{MgCl}_{2}$ gave a value of only $4.3 \mathrm{mS} . / \mathrm{cm}^{-1}$. However all Cl salts have caused a great damage to wheat seedlings, while the $\mathrm{SO}_{4}^{-2}$ salts of $\mathrm{Na}^{+}$or $\mathrm{Mg}^{+2}$ caused a little or no harm.

Actually the irrigation of wheat with $10 \mathrm{~g} / \mathrm{L}$ of $\mathrm{MgSO}_{4}$ solution tripled the seedling emergence and growth, as compared to $\mathrm{MgCl}_{2}$ solution. Besides, mixing a saline solution of $6 \mathrm{~g} \mathrm{NaCl} / \mathrm{L}$ with different levels of $\mathrm{MgSO}_{4}$ have clearly increased the growth of wheat tillers, maximum growth was obtained when mixing $2 \mathrm{~g} \mathrm{MgCl}_{2}$ with $6 \mathrm{~g} \mathrm{NaCl}$ with a total salinity of $8 \mathrm{~g} / \mathrm{L} . \mathrm{MgSO}_{4}$ solution tripled seedling growth as compared to $\mathrm{MgCl}_{2}$ solution.

In other words increasing salinity of irrigation water can give better growth conditions once a proper anion balance is maintained. It can also be noticed that $2 \mathrm{~g} \mathrm{MgSO}_{4}+6 \mathrm{~g} \mathrm{NaCl}$, which caused the best growth gave also the minimum salinity in the top soil.

Salt activity, salt balance and salt concentration in irrigation solutions are shown in Table 1. 
Response of wheat to the irrigation with salts of $\mathrm{Cl}^{-}$and $\mathrm{SO}_{4}{ }^{=}$is presented in plate 1. Soil pots, irrigated with $10000 \mathrm{ppm}$ sulfate solution showed a plant growth comparable to non saline water irrigation. $\mathrm{Cl}^{-}$solution on the other hand initiated a little or no growth.

TABLE 1. Effected of salt type and salt balance on EC values of irrigation water and of top soil and on yield of wheat seedlings.

A. Type of salt.

\begin{tabular}{|c|c|c|c|c|c|c|c|}
\hline \multirow{3}{*}{$\begin{array}{c}\text { Added } \\
\text { soluble } \\
\text { salts }\end{array}$} & \multirow{3}{*}{$\begin{array}{c}\text { Type } \\
\text { of Cation }\end{array}$} & \multicolumn{3}{|c|}{$\mathrm{Cl}^{-}$salts } & \multicolumn{3}{|c|}{$\mathrm{SO}_{4}^{-2}$ salts } \\
\hline & & \multicolumn{2}{|c|}{$\mathrm{EC}\left(\mathrm{mS} . \mathrm{cm}^{-1}\right)$} & \multirow{2}{*}{$\begin{array}{c}\text { Yield of } \\
\text { wheat } \\
\text { seedling (g) }\end{array}$} & \multicolumn{2}{|c|}{$\mathrm{EC}\left(\mathrm{mS} . \mathrm{cm}^{-1}\right)$} & \multirow{2}{*}{$\begin{array}{c}\text { Yield of } \\
\text { wheat } \\
\text { seedling } \\
\text { (g) }\end{array}$} \\
\hline & & $\begin{array}{l}\text { Irrig. } \\
\text { water }\end{array}$ & $\begin{array}{l}\text { Top } \\
\text { soil }\end{array}$ & & $\begin{array}{l}\text { Irrig. } \\
\text { Water }\end{array}$ & $\begin{array}{l}\text { Top } \\
\text { soil }\end{array}$ & \\
\hline Non & NormalWater & 0.35 & 1.5 & 20.8 & - & - & 20.8 \\
\hline \multirow{3}{*}{10 g..$^{-1}$} & $\mathrm{Na}^{+}$ & 14.8 & 6.0 & 6.5 & 11.3 & 4.2 & 15.3 \\
\hline & $\mathrm{Mg}^{+2}$ & 4.3 & 2.6 & 6.0 & 2.9 & 2.5 & 16.5 \\
\hline & $\mathrm{Ca}^{+2}$ & 4.8 & 2.8 & 5.5 & - & - & - \\
\hline $10{\mathrm{~g} . \mathrm{l}^{-1}}^{-1}$ & \multicolumn{4}{|c|}{ Salt mixture of $1: 1 ; \mathrm{NaCl}: \mathrm{MgSO}_{4}$} & 7.89 & 3.37 & 15.9 \\
\hline
\end{tabular}

B. Balance of Salt mixtures.

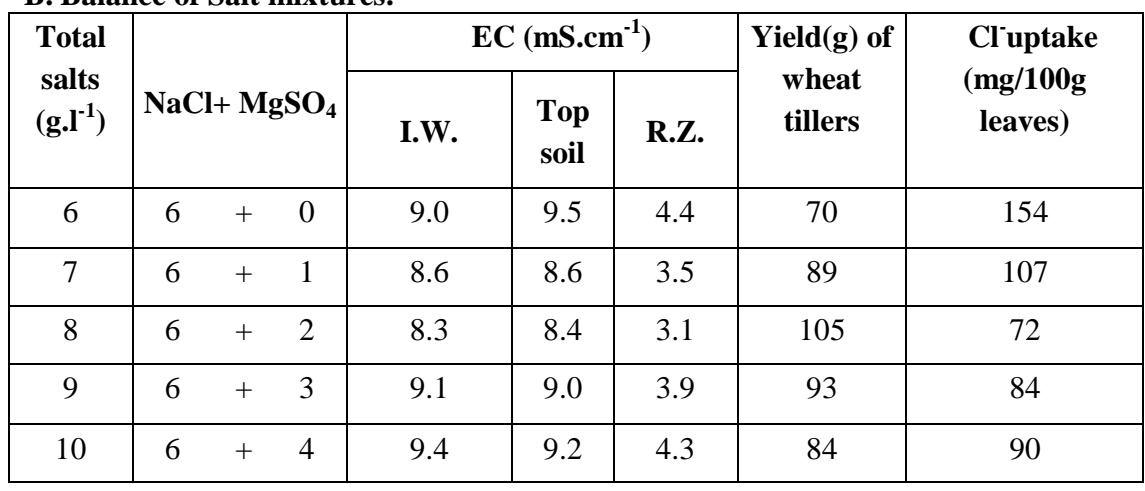

Form of applied $N$ fertilizer under salinity conditions

In case of using saline water of EC value of $8.5\left(\mathrm{mS.cm}^{-1}\right)$ for irrigating sorghum, urea proved to be the best $\mathrm{N}$ fertilizer. It decreased water salinity by $29 \%$ and Increased yield of sorghum by $34 \%$ as compared to $\left(\mathrm{NH}_{4}\right)_{2} \mathrm{SO}_{4}$ (Table 2$)$.

Calcium nitrate came second. Korkor and Hilal (1984) have previously disscused the interaction effect of saline water and nitrogen fertilization on crop yield. 

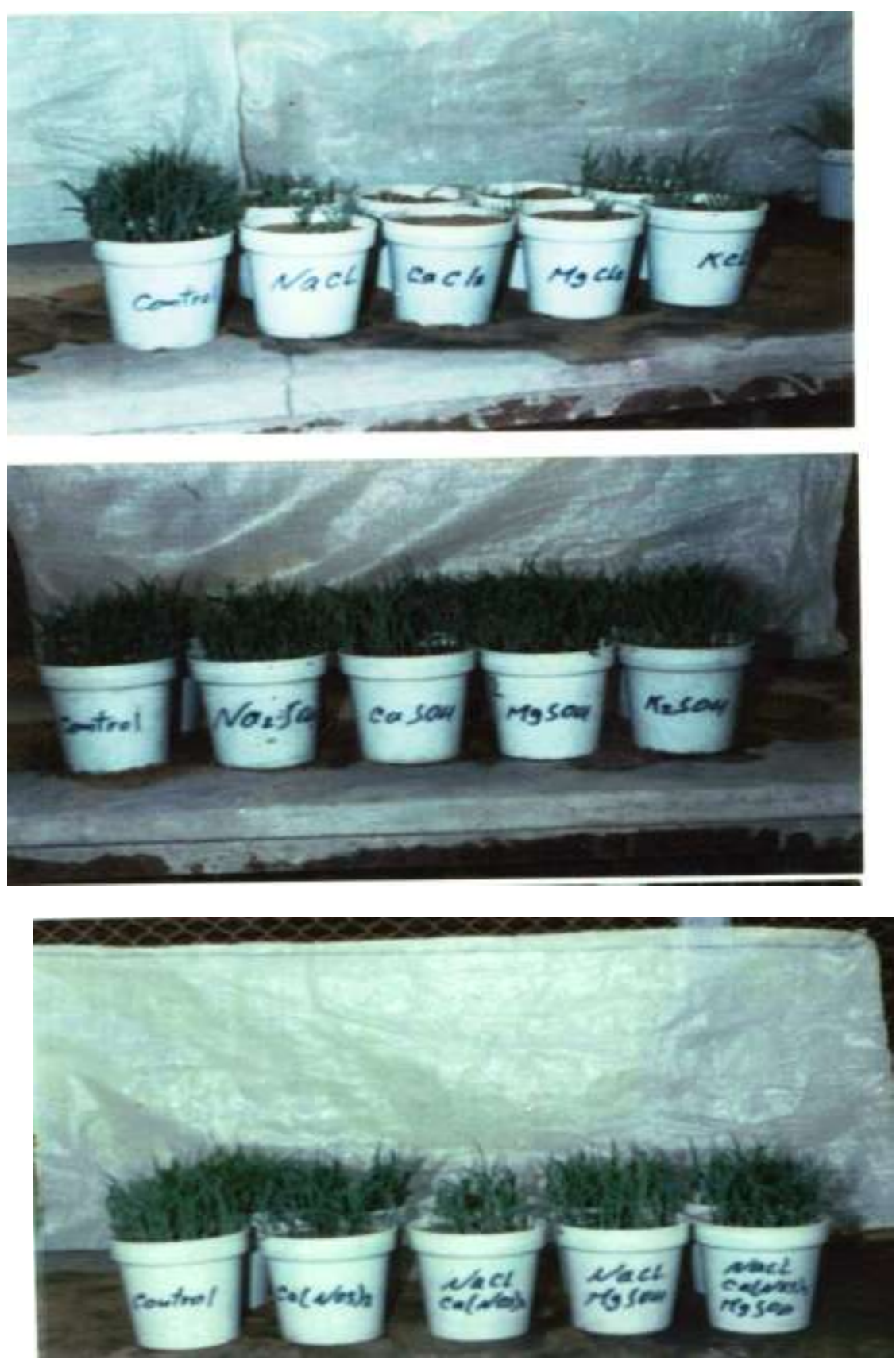

Plate 1. Response of wheat to $10000 \mathrm{ppm} \mathrm{Cl}^{-}$or $\mathrm{SO}_{4}{ }^{=}$solutions.

Egypt. J. Soil Sci. 53, No. 3 (2013) 
BENEFACTION OF SALINE WATER IRRIGATION IN DESERT SOILS... 319

TABLE 2. Effect of forms of $\mathrm{N}$ fertilizer on the $\mathrm{EC}$ values of irrigation water and Top soil and on yield of wheat seedlings.

\begin{tabular}{|c|c|c|c|c|}
\hline \multirow{3}{*}{ Salt Mixture } & \multirow{2}{*}{$\begin{array}{c}\text { Form of } \\
\text { added } \\
\text { Nitrogen }\end{array}$} & $\begin{array}{c}|c| \\
\text { Wrrigation } \\
\text { Water }\end{array}$ & Top soil & $\begin{array}{c}\text { Yield of } \\
\text { (45days) } \\
\text { sorghum }\end{array}$ \\
\cline { 3 - 4 } & Non & 8.5 & - & - \\
\cline { 2 - 4 } & Urea & 8.2 & 9.0 & 61.0 \\
\cline { 2 - 4 } $\mathrm{NaCl}+\mathrm{MgSO}_{4}$ & $\mathrm{Ca}\left(\mathrm{NO}_{3}\right)_{2}$ & 10.3 & 9.7 & 52.0 \\
\cline { 2 - 4 } & $\mathrm{NH}_{4} \mathrm{NO}_{3}$ & 10.5 & 10.6 & 44.1 \\
\cline { 2 - 4 } & $\left(\mathrm{NH}_{4}\right)_{2} \mathrm{SO}_{4}$ & 11.6 & 12.1 & 40.2 \\
\hline
\end{tabular}

\section{Salt Diffusion}

A set of one liter cylinders were prepared by placing $5 \mathrm{gm}$ salt in the bottom of each cylinder then filled with either MTW or with normal tap water. The effects of magnetizing water on a group of salts were tested by measuring EC at the top of the cylinder every few minutes.

Data in Table 3 indicate that magnetized water (MWT) has instantaneously accelerated the diffusion of certain salts and its upward movement in water jars and inhibited others. $\mathrm{Na} \mathrm{Cl}$ diffusion increased from 8.5 to 13 in only $5 \mathrm{~min}$, due to water magnetization. Its diffusion continued to increase to $30 \mathrm{~min}$. Sodium sulfate - diffusion increased in MWT for only $5 \mathrm{~min}$. but remained constant thereafter. On the other hand, diffusion of Super phosphate, $\mathrm{Zn}$ Sulfate and $\mathrm{Mg}$ Sulfate was slightly depressed by MWT. Effect of MWT on salt diffusion is variable.

TABLE 3. Upward diffusion of different salts and fertilizers.

\begin{tabular}{|l|c|c|c|}
\hline \multirow{2}{*}{ Salt type } & \multicolumn{3}{|c|}{ E.C. (m. mohs / cm ) at deferent minutes } \\
after adding water \\
\cline { 2 - 4 } & \multicolumn{3}{|c|}{ Normal Water } \\
\cline { 2 - 4 } & $\mathbf{5}$ minutes & $\mathbf{2 0}$ minutes & $\mathbf{3 0}$ minutes \\
\hline $\mathrm{Na} \mathrm{Cl}$ & 8.5 & 8.7 & 9.1 \\
$\mathrm{Na} \mathrm{NO}_{3}$ & 10.0 & 14.0 & 15.3 \\
$\mathrm{Na}_{2} \mathrm{SO}_{4}$ & 17.0 & 16.7 & 17.0 \\
\hline $\mathrm{KCl}_{\mathrm{KH}} \mathrm{PO}_{4}$ & $\mathbf{1 7 . 5}$ & $\mathbf{2 0 . 1}$ & $\mathbf{1 9 . 2}$ \\
$\mathrm{Super} \mathrm{phosphate}$ & 2.3 & 2.8 & 3.6 \\
\hline $\mathrm{Zn} \mathrm{Sulfate}$ & 1.5 & -- & 2.1 \\
$\mathrm{Cu} \mathrm{Sulfate}$ & $\mathbf{3 . 5}$ & -- & $\mathbf{3 . 6}$ \\
$\mathrm{Mg} \mathrm{Sulfate}$ & 1.6 & -- & 2.1 \\
\hline
\end{tabular}


Salt distribution and accumulation in homogenous soils

\section{a.Under drib irrigation}

Saline water irrigation of trees through a drip system of irrigation forms 3 different salinity zones around trees:

1. Salinity under the drip line is relatively the lowest.

2. At the wetting edge salinity is several times higher than that of irrigation water and than the salinity under drippers.

3. The third zone is mid distance between rows where great amounts of salts accumulate. This zone is relatively dry.

Distribution pattern of salts in these zones is shown in Table 4 to depend greatly on water salinity, type of tree cover, irrigation system and soil permiability.

\section{b. Under surface irrigation of leveled soil}

Wetting and drying cycles are applied for most of crops. Under such conditions, saturated conditions sustain for only few hours after irrigation but unsaturated conditions prevail for weeks during drying. Redistribution and accumulation of salts during drying is presented in Fig. 1. Upward movement of salts to the surface $6 \mathrm{~cm}$ occurred quickly; one day after irrigation.
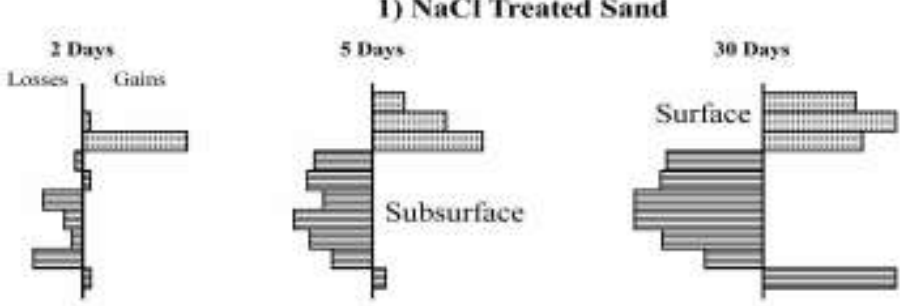

2) NaCI Treated Sandy Loam
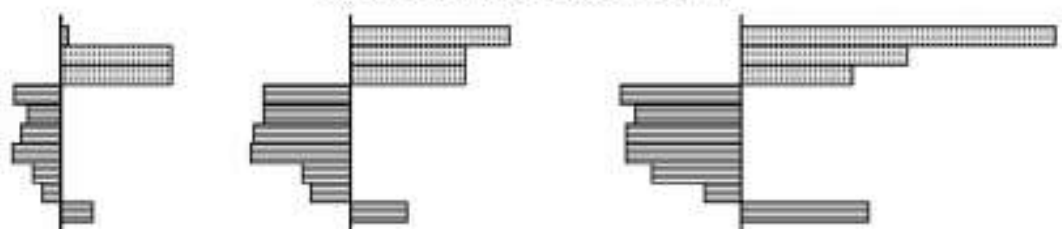

Gains and losses of salts in soil segments after drying.

Fig. 1. Salt movement and distribution in a homogenous sandy or a sandy loam soil. 
BENEFACTION OF SALINE WATER IRRIGATION IN DESERT SOILS ... 321

TABLE 4. Effect of irrigation water salinity (IWS) and tree cover on salt accumulation around trees.

\begin{tabular}{|c|c|c|c|c|c|c|}
\hline \multirow[b]{2}{*}{ Site } & \multirow{2}{*}{$\begin{array}{l}\text { Irrigation } \\
\text { water } \\
\text { salinity }(\mathrm{EC})\end{array}$} & \multirow[b]{2}{*}{$\begin{array}{l}\text { Tree } \\
\text { cover }\end{array}$} & \multirow{2}{*}{$\begin{array}{c}\text { Sample } \\
\text { depth } \\
(\mathrm{cm})\end{array}$} & \multicolumn{3}{|c|}{ Soil EC $\left(\mathrm{mS}^{2} \mathrm{~cm}^{-1}\right)$} \\
\hline & & & & $\begin{array}{c}\text { Under } \\
\text { drippers }\end{array}$ & $\begin{array}{c}\text { Wetting } \\
\text { edge }\end{array}$ & $\begin{array}{c}\text { Between } \\
\text { rows }\end{array}$ \\
\hline \multirow{3}{*}{1 Sadat City } & \multirow{3}{*}{$\begin{array}{l}2 \text { to } 2.5 \\
\left(\mathrm{mS} . \mathrm{cm}^{-1}\right)\end{array}$} & Grapes & $0-30$ & 2.6 & 17.5 & 38 \\
\hline & & Peaches & $0-30$ & 3.5 & 14.8 & 58 \\
\hline & & Apricot & $0-30$ & 2.4 & 10.7 & 70 \\
\hline \multirow{3}{*}{2 Serabiom } & \multirow{3}{*}{$\begin{array}{l}4.2 \text { to } 5.6 \\
\left(\mathrm{mS} . \mathrm{cm}^{-1}\right)\end{array}$} & \multirow{3}{*}{$\begin{array}{l}3 \text { Olive } \\
\text { farms }\end{array}$} & $0-30$ & 3.1 & 21.8 & 29 \\
\hline & & & $0-30$ & 5.1 & 19.5 & 48 \\
\hline & & & $0-30$ & 3.4 & 20.7 & 61 \\
\hline \multirow{3}{*}{$\begin{array}{c}3 \text { Serabiom } \\
\text { a- drip } \\
\text { irrigation }\end{array}$} & \multirow{3}{*}{$\begin{array}{c}8.3 \\
\left(\mathrm{mS} . \mathrm{cm}^{-1}\right)\end{array}$} & Olives & $0-30$ & 15.7 & 39.0 & 113 \\
\hline & & farm & $30-60$ & 6.1 & 9.1 & 33.4 \\
\hline & & profile & $60-90$ & 7.1 & 18.0 & 51.0 \\
\hline \multirow{3}{*}{$\begin{array}{c}3 \text { Serabium } \\
\text { b-subsurface } \\
\text { vertical } \\
\text { irrigation }\end{array}$} & \multirow{3}{*}{$\begin{array}{c}8.3 \\
\left(\mathrm{mS} . \mathrm{cm}^{-1}\right)\end{array}$} & \multirow{3}{*}{$\begin{array}{l}\text { Olives } \\
\text { farm } \\
\text { profile }\end{array}$} & $0-30$ & 5.6 & 10.8 & 17.6 \\
\hline & & & $30-60$ & 6.6 & 6.5 & 13.9 \\
\hline & & & $60-90$ & 7.4 & 6.7 & 11.5 \\
\hline
\end{tabular}

Under furrow-irrigation

At moderately saline conditions, the system of furrow irrigation, result in a salts accumulate to a dangerous level on the top of the furrow; the EC value on the top reaches about $60\left(\mathrm{mS}_{\mathrm{cm}} \mathrm{cm}^{-1}\right)$. On the other hand, the EC value at the bottom reaches only 2 to $3\left(\mathrm{mS} \mathrm{cm}^{-1}\right)$ which is completely safe for cultivating seeds at the bottom of the furrow, as shown in Fig. 2.

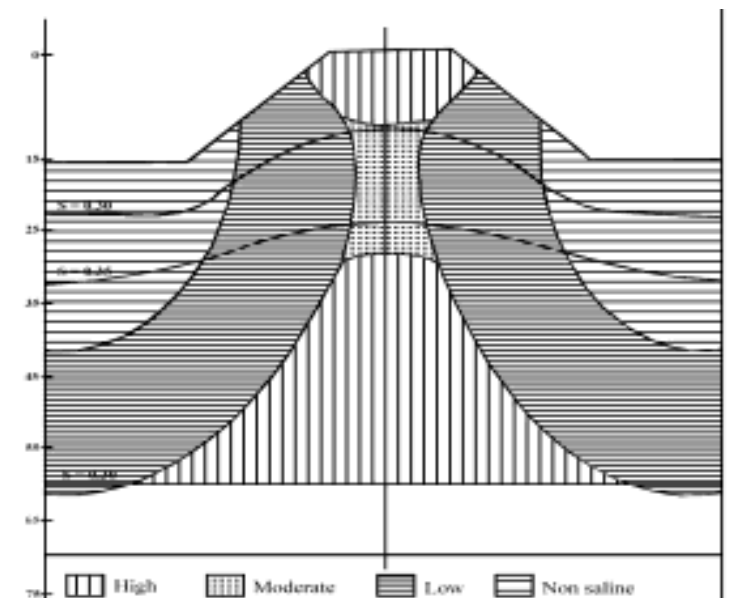

Fig. 2. Salt distribution under Furrow-Irrigation for salt affected sandy-loam soil.

Aspects of moisture and solute transport in soils as affected by soil stratification and moisture content were verified by Hilal and Shata (2000). Any 
type of soil column stratification, such as a layer of Sand / sandy loam layer or the opposite S / SL, suppressed the upward movement of salts and limited their accumulation on the surface. In the same time, such stratification has accelerated their downward movement to the bottom segment (Fig. 3). Induced gravel layer in the subsoil also prevent upward salt movement from layers below it, to layers above it.

For the best field management soil stratification should be seriously considered.

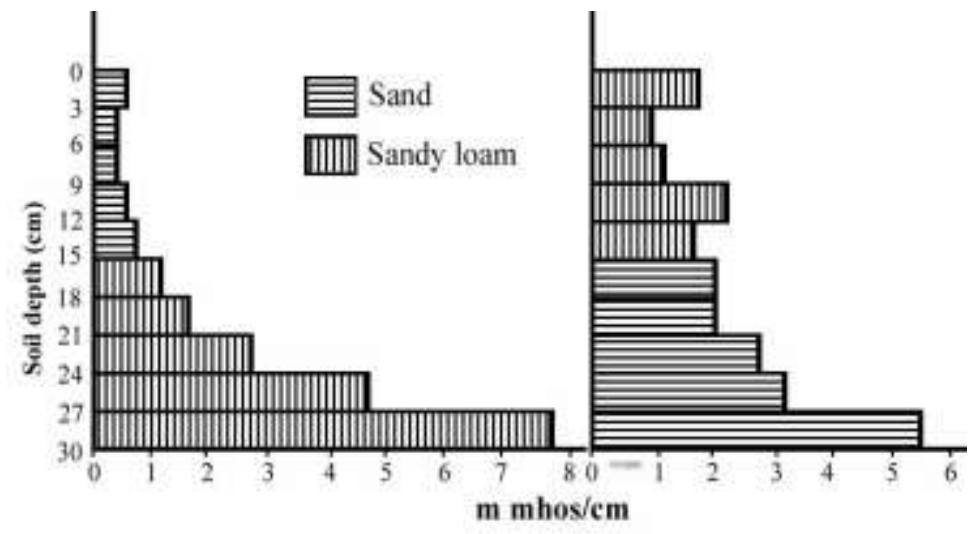

Fig. 3. Effect of stratification on salt distribution after drying.

\section{Field trails}

Field sites were selected to represent wide range of irrigation water salinity.

Small-scale field experiments were conducted at Ras-Sidre to evaluate the effect of NF applications on the performance of the relatively salt tolerant crops: wheat, barley, beats and onions.

Semi pilot scale experiments were conducted at Wadi El-Molak. Normal fertilization, NPK, practice was compared with NF application along with MTW. Test crops were wheat, sorghum and sesame.

Pilot scale application was also conducted in several sites. Magnetron UT6 is installed to irrigate 70 to 80 acres while model UT2 was used to irrigate 25 acres.

Changes in salt activity, salt accumulation, nutrient balance, plant growth, yield, nutrient availability and uptake were monitored in some or all of the selected sites. 


\section{Application of NF and control of salt accumulation}

The potential role of $\mathrm{S}$ in developing salt affected soils and for the efficient use of saline water in irrigation has been discussed elsewhere, Hilal (1990) and Hilal et al. (1993). If oxidized to sulfuric acid in soil, $\mathrm{S}$ reduces soil $\mathrm{pH}$, control salt accumulation and increases the availability of many nutrients in root zone. Mixing S with urea, bentonite and nutrients rich minerals, as in NF, promote the favorable effects of $S$.

Nile-Fertile $(N F)$ is a natural bio-mineral fertilizer formulated from elemental-S, group of nutrients rich minerals, urea and magnetic particles. NF is inoculated with acid producing and S-oxidizing bacteria.

Under the conditions of using highly saline water at Ras Sidre, NF application to topsoil, at a rate of $0.5 \mathrm{t}$./a, has doubled growth and yield of the relatively salt tolerant crops: wheat, barely, beats and onions. Control of salt accumulation in soil by NF application was the primary cause of the plant growth promotion (Table 5a,b).

Even under conditions of dry farming in areas of near saline water table NF application maintained better salinity and moisture conditions for wheat growth. In a lysimeter study simulating the conditions at Ras Sidre, a Saline water table of $10 \mathrm{~g} / \mathrm{L}$ was maintained at $120 \mathrm{~cm}$ depth either naturally or by subsurface irrigation.

Wheat grown in NF treated lysimeters succeeded to reach a dry weight of 34g. While the lysimeters treated with $\mathrm{CaNO}_{3}$ and super phosphate (NP) provided a wheat growth of only $8 \mathrm{~g}$ per lysimeter. Under conditions of dry farming, applying one complementary irrigation, with fresh water, has considerably reduced salinity and increased wheat growth several folds.

TABLE 5a. Effect of NF application on salt distribution and yield of relatively salt tolerant crops at the experimental farm of Ras Sidre.

\begin{tabular}{|c|c|c|c|c|c|c|c|}
\hline \multirow{3}{*}{$\begin{array}{c}\text { Water } \\
\text { Salinity }\end{array}$} & \multirow{3}{*}{ Crop } & \multicolumn{3}{|c|}{$\mathrm{EC}\left(\mathrm{mS} \mathrm{cm}^{-1}\right)$ in soil } & \multicolumn{3}{|c|}{ Yield $\left({\left.\mathrm{t} . \mathrm{a}^{-1}\right)}\right.$} \\
\hline & & \multirow{2}{*}{ Initial } & \multicolumn{2}{|c|}{ At harvest } & \multirow{2}{*}{ NPK } & \multirow{2}{*}{ NF } & \\
\hline & & & NPK & NF & & & \\
\hline \multirow{4}{*}{$\begin{array}{c}9.3 \\
\left(\mathrm{mS} . \mathrm{cm}^{-1}\right)\end{array}$} & Barley & 10.5 & 61.5 & 22.9 & 0.96 & 1.81 & Total \\
\hline & Wheat & 10.1 & 20.1 & 8.2 & 0.57 & 1.24 & Grains \\
\hline & Beets & 11.5 & 41.1 & 16.8 & 2.6 & 5.2 & Roots \\
\hline & Onion & 2.3 & 28.0 & 15.2 & 2.15 & 4.9 & Bulbs \\
\hline
\end{tabular}


TABLE 5 b. Effect of NF and NP fertilizers on topsoil salinity and yield of wheat.

\begin{tabular}{|c|c|c|c|c|c|c|c|}
\hline \multirow{3}{*}{$\begin{array}{l}\text { Yield and topsoil } \\
\text { parameters after } \\
\text { lysimeters setting }\end{array}$} & \multirow{3}{*}{$\begin{array}{c}\text { Days } \\
\text { after } \\
\text { setting }\end{array}$} & \multicolumn{6}{|c|}{ Irrigation and fertilizer treatments } \\
\hline & & \multicolumn{3}{|c|}{$\begin{array}{l}\text { Dry farming } \\
\text { (without } \\
\text { irrigation) }\end{array}$} & \multicolumn{3}{|c|}{$\begin{array}{c}\text { One deep complementary } \\
\text { Irrigation }\end{array}$} \\
\hline & & Non & $\mathbf{N P}$ & NF & Non & $\mathbf{N P}$ & NF \\
\hline \multirow{3}{*}{$\mathrm{EC}\left(\mathrm{mS} . \mathrm{cm}^{-1}\right)$} & 40 & 23.0 & 18.4 & 12.0 & 7.6 & 7.0 & 3.2 \\
\hline & 80 & 27.0 & 21.1 & 12.7 & 9.9 & 10.3 & 5.5 \\
\hline & 120 & 31.0 & 23.1 & 14.8 & 15.4 & 12.5 & 6.6 \\
\hline$\%$ Soil moisture & 120 & 3.9 & 5.8 & 7.6 & 5.0 & 6.2 & 8.1 \\
\hline Yield (dry wt. in g) & 120 & - & $8.2 \pm 3$ & $34 \pm 2$ & - & $80 \pm 1$ & $92 \pm 2$ \\
\hline
\end{tabular}

\section{Prospects of magnetic treatment of saline water in desert agriculture}

\section{Salt diffusion}

Magnetic water treatment effects on Salt diffusion were shown to be variable, due to differences in magnetic susceptibility. Upward Diffusion of $\mathrm{NaCl}, \mathrm{Na}_{2} \mathrm{SO}_{4}, \mathrm{~K} \mathrm{Cl}$ and $\mathrm{Cu}$ Sulfate increased in magnetized water. While that of $\mathrm{Na} \mathrm{NO}_{3}, \mathrm{KH}_{2} \mathrm{PO}_{4}, \mathrm{Mg}$ Sulfate and $\mathrm{Zn}$ Sulfate were decreased as shown in Table 6.

Effects of magnetized saline irrigation water on moisture loss and salt leaching

Four soil pots of $3 \mathrm{~kg}$ capacity each were irrigated with saline water having an E.C. value of $8.2 \mathrm{~m} . \mathrm{mohs} / \mathrm{cm}$, taken from a well at Ras Sidre; two pots were irrigated with magnetized water and the others with normal saline water.

Salinity analyses of leachates and soil pots are presented in Table 7, the first irrigation caused a leaching of $1.2 \mathrm{mg}$ salts per magnetized pot as compared to $0.89 \mathrm{mg}$ for normal pots; the rate of increase in salt removal by (MW) reached about $35 \%$ in the second one.

\section{Magnetic systems for water treatment}

A magnetron of $140 \mathrm{~mm}$ inside diameter model UT6 is installed on the main irrigation line, it allows for water discharge of $140 \mathrm{~m}^{3}$ per $\mathrm{hr}$ A magnetron of $50 \mathrm{~mm}$ inside diameter model UT2 that allows for $50 \mathrm{~m}^{3}$ per hr. when passing a magnetic field, irrigation water gains a magnetic moment and retain it for 24 to $48 \mathrm{hr}$. Magnetic treated saline water undergoes several changes in its physical properties (Takatchencko, 1997). It also exerts several effects on soil waterplant system. Besides, it enhanced nutrient mobility in soil and uptake by plants (Hilal and Helal, 2000 b).

Magnetic treatment of saline irrigation water at Serbium, decreased salt accumulation at the edge of droppers wetting zone ( Table 8).

Egypt. J. Soil Sci. 53, No. 3 (2013) 
Under olive trees, the removal of $\mathrm{Na}^{+}$from the wetting zone increased considerably by MTW, while the concentrations of $\mathrm{Ca}^{+2}$ and $\mathrm{Mg}^{+2}$ were increased. Such change in cation balance provided much better conditions for plant growth.

TABLE 6. Effect of magnetic water treatment (MWT) on the diffusion of different salts and nutrients.

\begin{tabular}{|c|c|c|c|c|c|c|}
\hline \multirow{2}{*}{ Salt type } & \multicolumn{6}{|c|}{ E.C. (m. mohs / cm ) at deferent minutes after adding water } \\
\cline { 2 - 7 } & \multicolumn{3}{|c|}{ Normal Water } & \multicolumn{2}{c|}{ Magnetized Water } \\
\cline { 2 - 7 } & $\begin{array}{c}\mathbf{5} \\
\text { minutes }\end{array}$ & $\begin{array}{c}\mathbf{2 0} \\
\text { minutes }\end{array}$ & $\begin{array}{c}\mathbf{3 0} \\
\text { minutes }\end{array}$ & $\begin{array}{c}\mathbf{5} \\
\text { minutes }\end{array}$ & $\begin{array}{c}\mathbf{2 0} \\
\text { minutes }\end{array}$ & $\begin{array}{c}\mathbf{3 0} \\
\text { minutes }\end{array}$ \\
\cline { 2 - 7 } & 8.5 & 8.7 & 9.0 & 13.0 & 14.0 & 14.8 \\
$\mathrm{Na} \mathrm{Cl}$ & 10.0 & 14.0 & 15.2 & 12.3 & 12.5 & 12.8 \\
$\mathrm{Na} \mathrm{NO}_{3}$ & 17.0 & 16.5 & 17.0 & 19.5 & 20.1 & 21.0 \\
$\mathrm{Na}_{2} \mathrm{SO}_{4}$ & & & & & & \\
& 17.5 & 20.1 & 19.2 & 21.0 & 24.0 & 23.5 \\
$\mathrm{~K} \mathrm{Cl}^{*}$ & 2.3 & 2.8 & 3.6 & 3.2 & 3.1 & 3.1 \\
$\mathrm{~K} \mathrm{H}_{2} \mathrm{PO}_{4}$ & & & & & & \\
$\mathrm{Super}_{\text {phosphate }}$ & 2.0 & -- & 2.1 & 1.85 & -- & 1.8 \\
$\mathrm{Mg} \mathrm{Sulfate}$ & 2.0 & -- & 2.1 & 1.85 & -- & 1.80 \\
$\mathrm{Zn} \mathrm{Sulfate}$ & 3.6 & -- & 3.6 & 3.0 & -- & 3.2 \\
$\mathrm{Cu}$ Sulfate & 1.6 & -- & 1.7 & 1.7 & -- & 2.2 \\
& & & & & & \\
\hline
\end{tabular}

Both sesame and sorghum have also responded well to MTW and NF application. MTW has also increased nutrients uptake by variable degrees depending on crop and element. Fe, $\mathrm{P}$ and $\mathrm{K}$ uptake of both crops responded to MTW more than $\mathrm{N}$ did. The responses of $\mathrm{Zn}$ and $\mathrm{Mn}$ were positive while there was no response to $\mathrm{Cu}$. The extent to MTW effects depend mainly on the magnetic susceptibility of elements and compounds

The rate of increase of salt removal by magnetized water reached $48 \%$ as compared to normal water.

Besides, the volume of leachates increased by $22 \%$ and $31 \%$ for the first and second irrigation with magnetized water. The amount of retained moisture per pot was shown to decrease by magnetic treatment. On the other hand, the water retention in the second leachate was taken as a measure for evaporation loss during the previous drying cycle, evaporation loss according to this estimation was shown to decrease greatly by magnetic treatment. In the first irrigation salt retention per pot was $10 \%$ greater in case of normal water compared to magnetized. Such percentage exceeded $130 \%$ in the second irrigation. 
TABLE 7. Salt and moisture retention in soil pots and estimated evaporation loss as affected by magnetizing saline irrigation water.

\begin{tabular}{|c|c|c|c|c|c|c|}
\hline \multirow[b]{2}{*}{ Parameter } & \multicolumn{2}{|c|}{$1^{\text {st }}$ Irrigation } & \multicolumn{2}{|c|}{$2^{\text {nd }}$ irrigation } & \multicolumn{2}{|c|}{ Total } \\
\hline & $\begin{array}{l}\text { Magnetized } \\
\text { water }\end{array}$ & $\begin{array}{c}\text { Normal } \\
\text { water }\end{array}$ & $\begin{array}{l}\text { Magnetized } \\
\text { water }\end{array}$ & $\begin{array}{c}\text { Normal } \\
\text { water }\end{array}$ & $\mathbf{M}$ & $\mathbf{N}$ \\
\hline $\begin{array}{l}\text { Irrigation water } \\
\text { Volume }\left(\mathrm{cm}^{3}\right)\end{array}$ & 750 & 750 & 200 & 200 & 950 & 950 \\
\hline E.C. $(\mathrm{m} . \mathrm{mohs} / \mathrm{cm})$ & 8.25 & 8.30 & 8.10 & 8.15 & - & - \\
\hline Salt added per pot (mg) & 4.36 & 4.36 & 1.14 & 1.14 & 5.5 & 5.5 \\
\hline $\begin{array}{l}\text { Leachates } \\
\text { Average volume }\left(\mathrm{cm}^{3}\right) \\
\text { E.C m.mohs/cm } \\
\text { Salt leached (mg / pot) }\end{array}$ & $\begin{array}{c}142 \\
12.30 \\
1.22 \\
\end{array}$ & $\begin{array}{c}116 \\
10.90 \\
0.89\end{array}$ & $\begin{array}{l}135 \\
9.85 \\
0.93\end{array}$ & $\begin{array}{c}103 \\
8.7 \\
0.69\end{array}$ & 2.15 & 1.53 \\
\hline $\begin{array}{l}\text { Soil pots } \\
\text { Retained moisture } \\
\text { Retained salts } \\
\text { Evaporation } \\
\left(\mathrm{cm}^{3} / \text { week) }\right.\end{array}$ & $\begin{array}{c}608 \mathrm{~cm}^{3} \\
3.14 \mathrm{mg} \\
-\end{array}$ & $\begin{array}{c}634 \mathrm{~cm}^{3} \\
3.45 \mathrm{mg} \\
-\end{array}$ & $\begin{array}{c}65 \mathrm{~cm}^{3} \\
0.21 \mathrm{mg} \\
65\end{array}$ & $\begin{array}{l}97 \mathrm{~cm}^{3} \\
0.5 \mathrm{mg} \\
97\end{array}$ & $\begin{array}{c}- \\
3.35 \\
65\end{array}$ & $\begin{array}{c}- \\
3.39 \\
97\end{array}$ \\
\hline
\end{tabular}

Effect of magnetic treatment of water on salt distribution around drippers in an olive farm

Salt removal from a soil pot, by applying excess magnetized or normal water, does not necessary apply under drip system of irrigation, where water movement is limited in both vertical and horizontal directions. For this reason it was necessary to monitor the changes in salinity and alkalinity in an olive farm at Serabiom, where the well water was moderately saline. Salinity analyses were conducted before and after the installation of a magnetron of 6 " diameter,

Table 8 compares the salinity of surface and subsurface soil at different locations around the drippers before and after installation of the magnetron, soil layers of non-cultivated area were free of salts. However, the salinity increase under drippers was limited in surface layer and much greater in root zone. Moreover the salinity increased 10 to 12 folds at the edges of wetted areas around the drippers where E.C. value reached 17 m.mohs / cm (Table 9).

TABLE 8. Effect of MTW on salt accumulation, cation balance and soil pH at the edge of wetting zone of olives (S: surface $(0-30 \mathrm{~cm})$, SS: subsurface).

\begin{tabular}{|c|c|c|c|c|c|c|c|c|c|}
\hline \multirow{2}{*}{$\begin{array}{c}\text { Soil } \\
\text { Samples }\end{array}$} & \multicolumn{10}{|c|}{ EC $\left(\mathbf{m S . c m}^{-1}\right)$} & \multicolumn{2}{c|}{ Soil pH } & \multicolumn{2}{c|}{$\mathbf{C a}^{+2}$ (ppm) } & \multicolumn{1}{c|}{$\mathbf{N a}^{+}(\mathbf{p p m})$} \\
\cline { 2 - 9 } & NW & MTW & NW & MTW & NW & MTW & NW & MTW \\
\hline & & \multicolumn{8}{|c|}{ (Sadat City) NF-treated plots } \\
\hline Site-1 & S & 13.0 & 3.9 & 8.0 & 7.5 & 215 & 218 & 980 & 500 \\
\hline & SS & 4.8 & 3.2 & 7.8 & 7.3 & 142 & 245 & 415 & 325 \\
\hline & & \multicolumn{8}{|c|}{ (Serabium) NPK-treated plots } \\
\hline Site-2 & S & 18.9 & 11.0 & 8.5 & 8.0 & & & & \\
\hline & SS & 9.5 & 6.9 & 8.1 & 7.7 & & & & \\
\hline
\end{tabular}

Egypt. J. Soil Sci. 53, No. 3 (2013) 
BENEFACTION OF SALINE WATER IRRIGATION IN DESERT SOILS ... 327

TABLE 9. Salt distribution in an olive farm before and after magnetron setting.

\begin{tabular}{|c|c|c|c|c|c|}
\hline \multirow{3}{*}{$\begin{array}{l}\text { Sample } \\
\text { location }\end{array}$} & \multirow{3}{*}{$\begin{array}{c}\text { Sample } \\
\text { depth } \\
\text { cm }\end{array}$} & \multicolumn{4}{|c|}{ Time of sampling } \\
\hline & & \multicolumn{2}{|c|}{$\begin{array}{c}\text { before } \\
\text { magnet. Setting }\end{array}$} & \multicolumn{2}{|c|}{$\begin{array}{l}6 \text { months after } \\
\text { magent. Setting }\end{array}$} \\
\hline & & $\begin{array}{c}\text { E.C. } \\
\text { m. mohs/cm }\end{array}$ & pH. & $\begin{array}{c}\text { E.C. } \\
\text { m.mohs } / \mathrm{cm}\end{array}$ & pH \\
\hline \multirow{3}{*}{$\begin{array}{l}\text { Non cultivated } \\
\text { area }\end{array}$} & $0-2$ & 1.37 & 8.9 & - & \\
\hline & $2-20$ & 0.58 & 9.5 & - & \\
\hline & $20-60$ & 0.60 & 8.8 & - & \\
\hline \multirow[t]{3}{*}{ Under dripper } & $0-2$ & 1.45 & 8.7 & 4.05 & 7.80 \\
\hline & $2-20$ & 2.17 & 8.5 & 3.95 & 7.86 \\
\hline & $20-60$ & 5.50 & 8.4 & 3.35 & 7.72 \\
\hline \multirow{3}{*}{ Wetting edge } & $0-2$ & 16.9 & 8.8 & 10.5 & 8.08 \\
\hline & $2-20$ & 7.9 & 8.6 & 5.80 & 8.02 \\
\hline & $20-60$ & 7.1 & 8.5 & 4.45 & 7.92 \\
\hline
\end{tabular}

Six months after fixing the magnetron, salinity at the wetting front decreased by $60 \%$ while that under droppers increased. However, soil alkalinity has dropped considerably at all tested locations after the setting of magnetrons. MWT accelerate 3 main functions:

(1) Leaching of excess soluble salts, (2) Lowering alkalinity, (3) Dissolving slightly soluble salts such as carbonates, sulfates and phosphates.

In fact, growth of olive trees has responded well to magnetron setting.

Ionic balance and uptake by citrus as affected by magnetized water

To verify such effect on accelerating the dissolving power of magnetized water, a second field evaluation was carried in an orchard where the soil is also sandy Loam but the irrigation water was slightly saline. Comparing salinity analysis of sites right ahead and right after magnetron placement, indicated a sharp increase in E.C. value and considerable drop in $\mathrm{pH}$ value of the site located after the magnetron (Table 10). Gradual decrease in salinity and increase in $\mathrm{pH}$ occurred by going further away from the magnetron.

It appears that the travelling distance of magnetized irrigation water through the irrigation line should be considered in application. However all magnetized samples were higher in E.C values and lower in $\mathrm{pH}$ compared to non magnetized one.

Data in Table 10 also indicate a greater reduction in $\mathrm{pH}$ of subsurface samples of the magnetized areas. However, $\mathrm{pH}$ reduction sliced down at lateral edges at $200 \mathrm{~m}$ distance from the main irrigation line. 
It was surprising to notice that magnetized water has doubled E.C., values in non saline area, but cause a great reduction in highly saline locations at lateral edges.

Considerable decrease in $\mathrm{Cl}^{-}$to $\mathrm{SO}_{4}^{\prime \prime}$ and $\mathrm{Na}^{+}$to $\mathrm{Mg}^{++}$ratios was also noticed in soil - water extracts of magnetized sites. Reduction in such ratios was shown to be very favorable for plant growth under high salinity conditions (Badre, 1997 and Hilal et al.,1997). Magnetic field weakens the bonds between certain ions with subsequent bonding amplification of others.

These changes result in a condition for ionic association, facilitated formation of ion pairs and more sophisticated aggregates and crystals. Such formation of ion pairs and ionic associations explains why the uptake of $\mathrm{Na}^{+}$by citrus leaves as shown in Table 6 was decreased to one half in magnetized sites while extractable $\mathrm{Na}^{+}$was doubled in these same sites as compared to normal plots. Analysis of citrus leaves 4 weeks after magnetron setting have shown slight variation in $\mathrm{Mg}^{+2}$ and $\mathrm{Na}^{+}$uptake and 10 to $15 \%$ increase in $\mathrm{Ca}^{+2}$ uptake in magnetized sites.

However 10 weeks later the rate of increase in $\mathrm{Mg}^{+2}$ uptake reached $15 \%$ and that of $\mathrm{Ca}^{+2}$ ranged between $70 \%$ to $140 \%$. These results indicate that magnetron effect on cations uptake was rather low as compared to the effect on $\mathrm{Cl}^{-}$and $\mathrm{SO}_{4}{ }^{=}$.

TABLE 10. Values of soil pH and E.C. in 1:1 soil water extracts at different traveling distances beyond the magnetron.

\begin{tabular}{|c|c|c|c|c|c|c|}
\hline \multirow{4}{*}{$\begin{array}{l}\text { Traveling distance of } \\
\text { magnetized water }\end{array}$} & \multirow{2}{*}{\multicolumn{2}{|c|}{$\begin{array}{l}\text { Sampling } 14 \text { weeks } \\
\text { after setting } \\
\text { On main line }\end{array}$}} & \multicolumn{4}{|c|}{ Sampling 22 weeks after setting } \\
\hline & & & \multicolumn{2}{|c|}{ On main line } & \multicolumn{2}{|c|}{ End of laterals } \\
\hline & $\mathbf{S}$ & SS & $\mathbf{S}$ & SS & $\mathbf{S}$ & SS \\
\hline & \multicolumn{6}{|c|}{$\longleftarrow$ E.C m. mohs $/ \mathrm{cm}$} \\
\hline $\begin{array}{c}\text { 1- ahead of magnet } \\
(\mathrm{NW})\end{array}$ & 1.15 & 1.23 & 1.60 & 1.12 & 7.15 & 3.57 \\
\hline beyond magnet (MW) & & & & & & \\
\hline 2- 150 to $550 \mathrm{~m}$ (aver) & 3.27 & 3.00 & 2.48 & 2.21 & 2.46 & 1.95 \\
\hline \multirow[t]{2}{*}{$3-750 \mathrm{~m}$} & 2.10 & 1.95 & 1.60 & 1.38 & 1.78 & 1.55 \\
\hline & \multicolumn{6}{|c|}{ Soil pH } \\
\hline 1- Normal & 7.89 & 7.90 & 8.07 & 8.15 & 8.05 & 8.10 \\
\hline Magnetized & & & & & & \\
\hline 2- 150 to $550 \mathrm{~m}$ (aver) & 7.18 & 7.18 & 7.63 & 7.42 & 7.66 & 7.56 \\
\hline $3-750 \mathrm{~m}$ & 7.55 & 7.60 & 7.97 & 7.82 & 7.92 & 7.85 \\
\hline
\end{tabular}

Such formation of ion pairs and ionic association explains why the uptake of $\mathrm{Na}^{+}$by citrus leaves (Table 11) was decreased to one half in magnetized sites

Egypt. J. Soil Sci. 53, No. 3 (2013) 
BENEFACTION OF SALINE WATER IRRIGATION IN DESERT SOILS ... 329

even though the soil extractable $\mathrm{Na}^{+}$was doubled in these same sites as compared to normal plot. Analysis of citrus leaves 4 weeks after magnetron setting have shown slight variation in $\mathrm{Mg}^{+2}$ and $\mathrm{Na}^{+}$uptake and 10 to $15 \%$ increase in $\mathrm{Ca}^{+2}$ uptake in magnetized sites. However 10 weeks later the rate of increase in $\mathrm{Mg}^{+2}$ uptake reached $15 \%$ and that of $\mathrm{Ca}^{+2}$ ranged between $70 \%$ to $140 \%$. These results indicate that magnetron effect on cations uptake was rather slow as compared to the effect on $\mathrm{Cl}^{-}$and $\mathrm{SO}_{4}{ }^{=}$concentration in leaves.

TABLE 11. Uptake of some cations and anions by citrus leaves 4 and 14 weeks after magnetron placement

\begin{tabular}{|c|c|c|c|c|c|}
\hline \multirow[b]{2}{*}{ Sampling site } & \multicolumn{5}{|c|}{ Uptake of ions by leaves } \\
\hline & $\begin{array}{l}\mathrm{Ca}^{+2} \\
\mathrm{ppm}\end{array}$ & $\begin{array}{l}\mathrm{Mg}^{+2} \\
\mathrm{ppm} \\
\end{array}$ & $\begin{array}{l}\mathrm{Na}^{+} \\
\text {ppm }\end{array}$ & $\begin{array}{l}\mathrm{Cl}^{-} \\
\text {ppm }\end{array}$ & $\begin{array}{l}\mathrm{SO}^{=}{ }_{4} \\
\mathrm{mg} / \mathrm{g}\end{array}$ \\
\hline \multicolumn{6}{|l|}{ Dec. 1997} \\
\hline (1) Normal & 650 & 246 & 28.0 & 14.6 & 2.4 \\
\hline (2) M.W & 762 & 257 & 30.0 & 16.0 & 1.5 \\
\hline (3) M.W & 605 & 259 & 29.0 & 16.3 & 1.8 \\
\hline (4) M.W & 685 & 258 & 26.0 & 16.1 & 2.0 \\
\hline (5) M.W & 595 & 249 & 27.0 & 15.8 & 2.1 \\
\hline \multicolumn{6}{|l|}{2 Mar. 1998} \\
\hline (1) Normal & 510 & 470 & 57.5 & 19.8 & 2.15 \\
\hline (2) M.W & 1210 & 540 & 27.0 & 15.0 & 1.40 \\
\hline (3) M.W & 860 & 525 & 30.0 & 14.2 & 1.60 \\
\hline (4) M.W & 810 & 520 & 31.0 & 14.0 & 1.85 \\
\hline (5) M.W & 670 & 480 & 40.0 & 16.0 & 1.90 \\
\hline
\end{tabular}

\section{Conclusions}

1. The E. C. values of saline solutions were less dependent on salt concentration rather than on ion activity. Ionic balance was more effective on yield reduction than salt concentration.

2. Chloride salts drastically reduced growth of the tested plants, while sulphate salts upgraded plant growth. Applying $2 \mathrm{gm}$ of $\mathrm{MgSO}_{4}$ to $5 \mathrm{gm} /$ liter of $\mathrm{NaCl}$ solution caused a reduction in $\mathrm{EC}$ value of the final solution and increased wheat yield to $139 \%$ compared to control.

3. Urea was the best nitrogen fertilizer form, it achieves the greatest plant yield, $157 \%$ in Sorghurm and $116 \%$ in wheat yield compared to ammonium sulphate treatment.

4. Subsurface irrigation maintained lower salinity levels rather than surface irrigation. EC values in top soil recorded 17.3 through period of 120 days while salt concentration increased to $20.6 \mathrm{dS} / \mathrm{m}$ through the same period 
with surface irrigation. In addition, applying one non saline water delayed salinity rise 60 days and dropped soil salinity by 50 to $60 \%$ in- root zone and also reduced salt built up in top soil to $14.8 \mathrm{dS} / \mathrm{m}$ after 120 days.

5. An impeded gravel layer of $5 \mathrm{~cm}$ thickness at depth of $30 \mathrm{~cm}$ under surface had a positive effect on raising moisture content and reducing salt concentration of soil layer above it. Such stratification work as a trap for salts due to causing poor continuity in capillary path ways, difference in soil water suction and disorder in water and salt distribution.

6. Calcium nitrate and super phosphate in soil columns that treated with one nonsaline water irrigation maintained the highest levels of salts in top soil reached to 7.5 and $10.1 \mathrm{dS} / \mathrm{m}$ in the first 60 days of incubation compared to only $1.9 \mathrm{dS} / \mathrm{m}$ for control treatment. But after 120 days the accumulation of salts was sharply increased to $14.6 \mathrm{dS} / \mathrm{m}$ in the unfertilized soil compared to 10.5 and 14.4 for calcium nitrate and super phosphate respectively. While SFM treatment through the whole period could control salinity rise which did not exceed than6.4 dS/m for 120 days. Moreover, SFM in soil columns that subjected to saline water table was very effective in reducing salt concentration in top soil and subsoil $550 \mathrm{~cm}$ layer which maintained the lowest salt content acceptable for plant growth.

FM also maintained much better ionic balance of $\mathrm{Na}^{+}$to $\mathrm{Mg}^{++}$and $\mathrm{C1}^{-}$to $\mathrm{SO}_{4}^{=}$ratios.

7. Under surface irrigation with $1 \% \mathrm{NaCl}$ saline solution, wheat dry weight gave $50 \%$ for nonsaline water with NPK usual fertilizers and a yield of $69 \%$ with SFM application.

Under the condition of subsurface irrigation, wheat yield gave $28 \%$ with NPK of nonsaline water while. It reached to $40 \%$ with SFM application. Applying one deep nonsaline water irrigation gave a remarkable increase in wheat dry weight reaching $92 \%$ with NPK and gave the highest yield of $102 \%$ with SFM application.

8. Inducing $\mathrm{Cl} / \mathrm{SO}_{4}$ balance by applying $\mathrm{MgSO}_{4}$ as a water amendment or Nile Fertile as a soil amendment was very effective on plant response. Applying 2 gm of $\mathrm{MgSO}_{4}$ to the saline solution of $5 \mathrm{gm} /$ liter $\mathrm{NaCl}$ caused significant increase in wheat total yield reached to $112 \%$ and in grain yield reached to $124 \%$ and also increased sorghum dry weight to $121 \%$ as percent of control. Moreover, application of SFM to the soil recorded the highest yield response reached to $120 \%$ in wheat total yield and $137 \%$ in grain yield and reached to $129 \%$ in sorghum dry weight.

9. Soil analysis of North Eastern Coast profiles near Al-Arish valley revealed that soil salinity was quite low and very suitable for palm trees until the depth of water table. Subsoil of the profiles were holding available fresh

Egypt. J. Soil Sci. 53, No. 3 (2013) 
BENEFACTION OF SALINE WATER IRRIGATION IN DESERT SOILS ... 33

water at relevant depths to sustain plant growth. Fresh water table is continuously moved upward and feeding the roots of the palm trees

Data obtained from the model of feeding subsurface saline water indicated that SFM application increased wheat grains yield to $135 \%$ and sorghum dry weight to $142 \%$. Moreover SFM application along with one deep fresh water irrigation gave the highest increase in wheat grain yield reached to $143 \%$ and in sorghum dry weight reached to $157 \%$.

10. Mixing of SFM with the salt affected soil of OmmShehianfarm coupled with fertigation of urea was able to correct salt balance, reduced soil salinity, maintained better nutrient content for plant uptake and achieved the best barely performance reached to $165 \%$ as compared to fertigation with ammonium sulphate.

\section{References}

Badre, M. (1997) Management and fertilization of salt affected soils under limited supply. Ph.D. Thesis, Azhar, Univ.

Hilal, M.H. (1990) Sulur in Desert Agro - Systems. Proc. Middle East Sulfur Symposium. Cairo, Egypt (1990) Feb.

Hilal, M., Abed, F. and Badre, M. (1997) Corrective techniques for soil and irrigation water salinity in desert agro system. Proceedings, Salt Affected Soils, Cairo , Egypt 22-28 sept., 1997 .

Hilal, M. and korkor, S. (1993) "Sulfur and Irrigation Management For Salinity Control in Desert Soils", V. I pp. 479-483, Toward The Rational Use of High Salinity Tolerant Plants Kluwer Academic Publishers, Netherlands.

Hilal, M.H. and Helal, M.M. (2000) Application of magnetic technologies in desert agriculture, I- seed germination and seedling emergence of some crops in a saline calcareous soil. Egyptian J. Soil Sci. 40(3): 413-422.

Hilal, M.H. and Helal, M.M. (2000) Application of magnetic technologies in desert agriculture, II- Effect of magnetic treatments of irrigation water on salt distribution in olive and citrus fields and induced changes of ionic balance in soil and plant. Egyptian J. Soil Sci. 40(3): 423-435.

Hilal, M.H. and Shata, S.M. (2000) Some aspects of moisture and solute transport in soils as affected by soil stratification and moisture content. Egypt. J. Appl. Sci. 15, (7).

Ibrahim, S.M. (1999) Effect of the application of Sulphur Fertilizer Mixture on the movement of some nutrients in rhizosphere zone. M.Sc., Ain Shams Univ.

Egypt. J. Soil Sci. 53, No. 3 (2013) 
Korkor, S.A. and Hilal, M.H. (1976) Use of Saline Water For Irrigating Wheat Crop. Egypt. J. Soil Sci. 16 (2) .

Korkor, S.A. and Hilal, M.H. (1984) Interaction effect of saline water and nitrogen fertilization on crop yield: I-Stimulation effect of moderate salinity level on the yield of wheat. Proceeding of the Reuse Work Shop, Cairo, Mar., 1984.

Takashinko, Y. (1997) Hydro magnetic systems and their rolls in creating micro climate, Symposium On Salt Affected Soils. Cairo, Egypt, Sept., 1997.

Zhu, T.y., Sheng, D.G., Han, C.J. and Liu, H.W. (1986) Studies on the effectiveness of magnetized water in improving saline soils, Irrigation Drainage Abstracts 012 - 01629.

(Received 31/10/2012; accepted 30/3/2014) 
BENEFACTION OF SALINE WATER IRRIGATION IN DESERT SOILS... 333

$$
\text { قصطف آلأقي ري الصحى واستغلال المياه ـ المركز القومي للبحوث ـ الجيزة - مصر. }
$$

تعاني نظم الزراعة الصحراوية عادة من فقر فى خصوبة الإبة التربة ومن نراكم

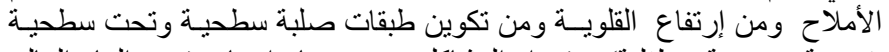

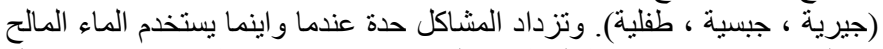

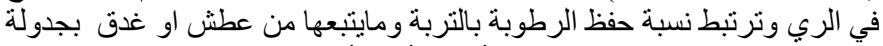

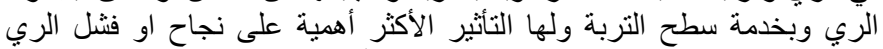

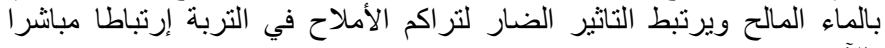
بالآتي:

$$
\begin{aligned}
& \text { (أ) توزيع الأملاح حول و أسفل خطوط الري. }
\end{aligned}
$$

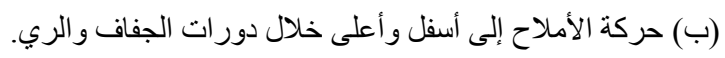

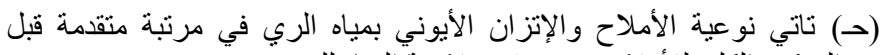

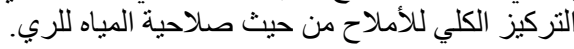

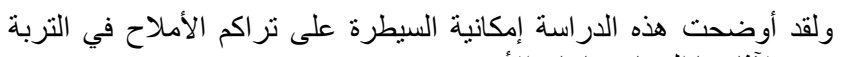

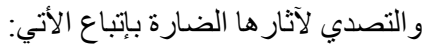

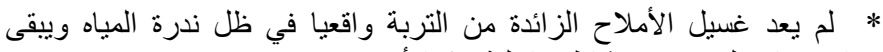

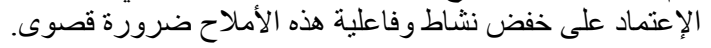
* إحداث نوازن ملحي وأيوني بالمحلول الأرضي وخاصة نسبة ال

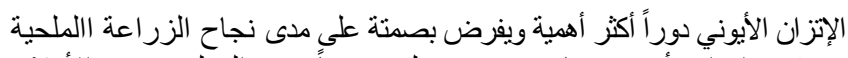

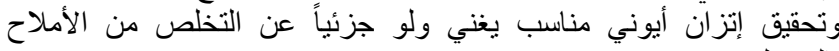
* خدمة مناسبة للحقل حسب نوع المحصول مثل الزراعة اسفل خطوط او الزراعة في شرائح طويلة

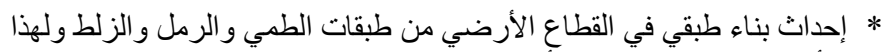

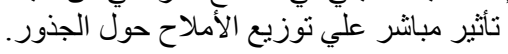

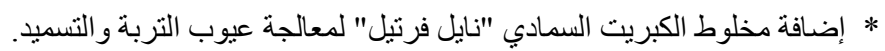

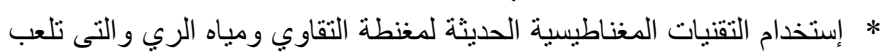

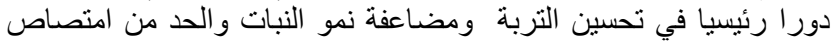
المعادن الثقيلة.

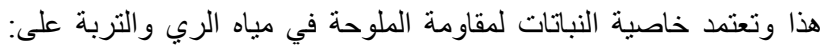

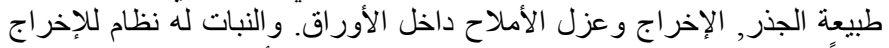

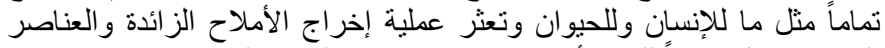

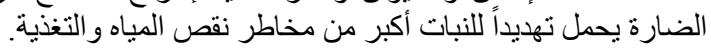

